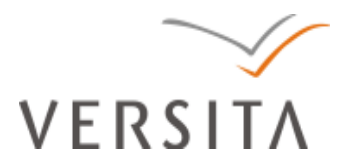

Folia Oeconomica Stetinensia

DOI: $10.2478 / \mathrm{v} 10031-010-0007-5$

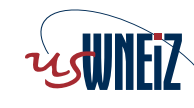

Wydzial Nauk Ekonomicznych i Zarządzania
Uniwersytetu Szzzecińskiego

\title{
INNOVATION PROCESS MODELS WITH EMPHASIS \\ ON OPEN INNOVATION MODEL
}

\author{
Katarzyna Kozioł-Nadolna, Ph.D. \\ Faculty of Economics and Management \\ University of Szczecin \\ Mickiewicza 64, 71-101 Szczecin, Poland \\ email:kkoziol@univ.szczecin.pl \\ Arkadiusz Świadek, Prof. \\ University of Zielona Góra \\ Podgórna 50, 65-246 Zielona Góra, Poland \\ email:a.swiadek@wez.uz.zgora.pl
}

Received 14 November 2010, Accepted 12 April 2011

\begin{abstract}
This article presents different models of innovation processes and focuses in particular on the open innovation. The empirical part is based on the findings on the innovation cooperation of enterprises in the EU and OECD (these data, among others, determine the open innovation). At the end of the article there is a case study of Nokia which implements the open innovation in its innovation activity. The aim of this article is to present the paradigm of the open innovation processes. This approach concentrates on sharing knowledge, i.e. making new solutions available to other units by means of e.g. license sale. The open innovation business model takes advantage of both internal and external sources of ideas without a fear that a company's own ideas when transferred to another organization will lead to the company's loss of profits coming from this idea. The formal framework of an organization is just a symbolic one and makes the flow of knowledge between the organization and its environment possible. The enterprises that adopt the open innovation strategy both enthusiastically develop ideas which were created by others as well as make their own ideas available to other organizations that find them more interesting.
\end{abstract}

Keywords: innovations, innovation process, open innovation.

JEL classification: $\mathrm{O} 30$. 


\section{Introduction}

The $21^{\text {st }}$ century strengthened the substantial changes on the market, which made enterprises change their innovation models. The innovation process is becoming more expensive and risky due to a global competition, a short product cycle, technological progress. As a consequence, enterprises start to share risk doing research with other enterprises and organizations, apply the open innovation model and enter enterprise networks.

\section{The models of innovation processes}

The innovation landscape in the world has changed as a result of the emergence of new phenomena, e.g. fast and easy information and technology transfer, technological progress, knowledge diffusion, electronic data exchange, a global market, a global consumer. Hence, many enterprises have not changed their innovation model.

When defining an innovation process we can distinguish two definitions. Following Schumpeter, the innovation process is a certain sequence of events: starting from an idea (invention), through implementation (innovation) and dissemination (imitation) ${ }^{1}$.

W. Janasz defines an innovation process as generating an innovation idea (regardless of what idea it is about or what area of innovation activity it is created on), then creating, designing and the first implementation. The main event in this kind of a process is the implementation of a new product or solution ${ }^{2}$.

The innovation process, as the definition says, consists of phases, stages connected with each other by different interactions.

We can look at innovation processes from different perspectives: economy, enterprise or a separate innovation. No matter which analysis we use, an innovation process generally consists of two phases: the creation of an innovation and its dissemination.

Innovation models have evolved from simple linear models. Good examples are: the technology-push model (up to the second half of the 1960s) and the market pull model (in the 1970s). More recent innovation models try to build more complexity and interaction into the framework and explicitly stress the need for openness towards external partners in innovation and R\&D. The "third-generation" innovation model combines the technology-push and need-pull models by stressing linkages and feedback loops between R\&D and marketing. The subsequent integrated model of the 1980s ("fourth-generation") emphasised innovation as a broadly parallel process with cross-functional integration and parallel development within the company and with external collaborators. 
R. Rothwell claimed at the beginning of 1990s that there were five generations of innovation models $^{3}$. His last 'fifth-generation' model combines integration networking with information technology, based on networking of marketing, R\&D, production and customers. However, this model constantly has the same structure of the innovation process $(\mathrm{R} \& \mathrm{D}$, production, customer, marketing), like models of the 'first-generation' (Table 1).

Table 1. Six generations of innovation models

\begin{tabular}{|l|l|}
\hline \multicolumn{1}{|c|}{ Generation } & \multicolumn{1}{c|}{ Key features } \\
\hline First and second & The linear models - need-pull and technology-push \\
\hline Third & Interaction between different elements and feedback loops among them - the coupling model \\
\hline Fourth & $\begin{array}{l}\text { The parallel lines model, integration with the firm, upstream with key suppliers and downstream } \\
\text { with demanding and active customers, emphasis on linkages and alliances }\end{array}$ \\
\hline Fifth & Systems integration and extensive networking, flexible and customised response, continuous \\
\hline Sixth & Open innovation, self-learning system \\
\hline
\end{tabular}

Source: own study on the basis Rothwell (1994), p. 7-31.

Can we already start talking about the "sixth-generation" innovation model? The answer seems to be positive. The end of 1990 s and the first decade of the $21^{\text {st }}$ century brought new solutions, structures and, finally, new approach towards development. Thus, the 'sixthgeneration' model is an answer to the changes in the global environment and its influence on enterprises. Moreover, the enterprises themselves have changed: their structure, ties (so networking enterprise emerged), emphasis on cooperation. In this model attention is paid to knowledge as a separate category and the processes managing the knowledge as well as learning processes. Innovation processes should be planned in a way to enable the following: creating new knowledge, managing existing knowledge, storing up knowledge, transfer of knowledge or using it again. Different kinds of boundaries are crossed: between enterprises, between sectors participating in innovation processes, in taking advantage of the experience of many organizations and their employees. Finally, new problems emerged ${ }^{4}$, i.e. the protection of intellectual property and regulations in an innovation chain.

The $21^{\text {st }}$ century strengthened the substantial changes on the market, which made enterprises change their innovation models. The innovation process is becoming more expensive and risky due to a global competition, a short product cycle, technological progress. As a consequence, enterprises start to share risk doing research with other enterprises and organizations, apply the open innovation model and enter enterprise networks. 


\section{Open innovation - the new paradigm}

Nowadays, it is more and more difficult to create innovations on a world scale, taking advantage of own resources. Innovations on a company or state scale (i.e. diffussion of innovations) are more common. Spontanious inventions made by ingenious inventors working alone are rare. The traditional opinion that an innovation derives from one's great mind full of new ideas is not true any more, as we observe our reality. Modern innovations are the outcome of systematic, often very expensive research which require a cooperation of many units or bigger teams representing different fields of knowledge and various institutions. Our today's market with its global competition constantly makes companies release new product. A new approach towards the innovation process has emerged, i.e. the open innovation model ${ }^{5}$.

The assumption that companies can and should use both external and internal ideas for their innovations processes is basic here. The open innovation business model takes advantage of both external as well as internal souces of ideas without a fear that some company's own idea when used by others will lead to this company's loss of profits coming from this idea. Quite the opposite, companies are unable to take advantage of all their ideas by themselves, so they share them willingly with their environment, which results in a higher number of innovative products. Such good productivity would not be possible in closed processes.

In the open strategy of innovations the following rule is the most basic: the maximization of values coming from different ideas (both company's own ideas as well as the external ones). This approach means that the formal framework of organization is just symbolic and does not stop the flow of knowledge between the organization and its environment. Companies that adopt the open innovation strategy both enthusiastically develop ideas which were created by others as well as make their own ideas available to other organizations which find them more interesting. Sometimes company's own ideas are (transferred) to other enterprises deliberately (e.g. to the start-ups) in order for them to be developed without the company's internal powers' influence.

In the closed approach, organizations do not share their knowledge and, moreover, their ideas stay inside an enterprise, being assessed at various levels. A lot of ideas are rejected and never used. On top of that, they are eliminated, not by the market or consumers, but by the enterprise employees who find the ideas irrelevant or useless at some moment.

The concept of the open innovation is new neither in the literature of this subject nor in enterprises' activity. However, no sooner was a broad discussion launched on the subject between theoreticians and practitioners than H.W. Chesbrough's book was published in 2003 under this very title ${ }^{6}$. 
Table 2. Definitions of open innovation

\begin{tabular}{|c|c|c|}
\hline Author & Reference & Definition \\
\hline H. Chesbrough & $\begin{array}{l}\text { Open innovation. The New } \\
\text { imperative for creating and } \\
\text { profiting from technology, Harvard } \\
\text { Business School Press, Boston } \\
2003\end{array}$ & $\begin{array}{l}\text { Open innovation is a paradigm that assumes that firms } \\
\text { can and should use external ideas as well as internal } \\
\text { ideas, and internal and external paths to markets, as the } \\
\text { firms look to advance their technology. Open innovation } \\
\text { combines internal and external ideas into architectures } \\
\text { and systems whose requirements are defined by } \\
\text { a business model }\end{array}$ \\
\hline H. Chesbrough & $\begin{array}{l}\text { Open Business Models: How } \\
\text { to Thrive in the New Innovation } \\
\text { Landscape, Harvard Business } \\
\text { School Press, Boston } 2006\end{array}$ & $\begin{array}{l}\text { Open innovation is the purposive inflows and outflows } \\
\text { of knowledge to accelerate internal innovation and } \\
\text { expand the markets for external use of innovation Open } \\
\text { innovation means that companies should make much } \\
\text { greater use of external ideas and technologies in their } \\
\text { own business, while letting their unused ideas be used } \\
\text { by other companies. This requires each company to } \\
\text { open up its business model to let more external ideas } \\
\text { and technologies flow in from the outside and let more } \\
\text { internal knowledge flow to the outside }\end{array}$ \\
\hline $\begin{array}{l}\text { J. West, } \\
\text { W. Wanhaverbeke } \\
\text { and H. Chesbrough }\end{array}$ & $\begin{array}{l}\text { Open Innovation: Researching } \\
\text { a New Paradigm, Oxford } \\
\text { University Press, } 2006\end{array}$ & $\begin{array}{l}\text { Open innovation is both a set of practices for profiting } \\
\text { from innovation, and also a cognitive model for creating, } \\
\text { interpreting and researching these practices }\end{array}$ \\
\hline $\begin{array}{l}\text { J. West and } \\
\text { S. Gallagher }\end{array}$ & $\begin{array}{l}\text { Challenges of Open Innovation: } \\
\text { The Paradox of Firm'Investment } \\
\text { on Open Source Software, R\&D } \\
\text { Management, Vol. 36, No. 3, } \\
\text { p. 319-331, } 2006\end{array}$ & $\begin{array}{l}\text { Open innovation systematically encourages and } \\
\text { explores a wide range of internal and external sources } \\
\text { for innovation opportunities, consciously integrates that } \\
\text { exploration with firm capabilities and resources, and } \\
\text { broadly exploits those opportunities through multiple } \\
\text { channels }\end{array}$ \\
\hline Ch. Leadbeater & $\begin{array}{l}\text { Open Business (2007), Open } \\
\text { Platform to Develop and Share } \\
\text { Innovative New Business Ideas } \\
\text { www.openbusiness.cc/2007/03/14/ } \\
\text { two-faces-of-open-innovation }\end{array}$ & $\begin{array}{l}\text { There are two faces of open innovation: Open Innovation } \\
\text { IN is the basic model where ideas flow into companies } \\
\text { from different sources (crowdsourcing) } \\
\text { Open Innovation OUT is where a group of people, } \\
\text { a movement, sometimes a company, create a kernel or } \\
\text { a platform, with some tools, onto which people can add } \\
\text { their ideas and contributions. } \\
\text { Open Innovation IN narrows down a wider set of } \\
\text { contributions into a funnel of corporate development. } \\
\text { Open Innovation OUT is designed to allow a process } \\
\text { of evolutionary innovation that accretes and grows as } \\
\text { each new person adds their piece of information, code } \\
\text { or module }\end{array}$ \\
\hline $\begin{array}{l}\text { Procter \& Gamble: } \\
\text { Innovation Strategy }\end{array}$ & $\begin{array}{l}\text { www.scienceinthebox.com/ } \\
\text { en_UK/research/innovation- } \\
\text { strategy_en.html }\end{array}$ & $\begin{array}{l}\text { Our innovation strategy is an approach we call Connect } \\
\text { + Develop through which Procter \& Gamble is seeking } \\
\text { to build a global innovation network. While we invent } \\
\text { most of our products in our own labs, we want half of } \\
\text { the new ideas to come from outside. Connect + Develop } \\
\text { is our way to encourage more open innovation. It is } \\
\text { a way of leveraging internally and externally developed } \\
\text { innovation assets. We are developing mutually beneficial } \\
\text { relationships with the talents and technologies of today's } \\
\text { most inspired minds and capabilities }\end{array}$ \\
\hline
\end{tabular}

Source: Open Innovation in the Global Networks, OECD 2008. 
The novelty of Chesbrough's concept is based on a fact that the process of open innovation became an integral part of the innovation strategy of an enterprise and its business model. In the first decades of the $20^{\text {th }}$ century industrial enterprises in the USA cooperated and commissioned solutions in independent R\&D laboratories. We can say that they used the open innovation model $^{7}$. However, the situation changed drastically after the 2nd World War. In 1950s and 1960s the first generation model of the innovation process (described in the previous chapter) with its closed approach was in the lead. The new open innovation model contrasts with this approach.

A vast majority of enterprises has no doubts that there has been a change in the perception of the innovation process and its implementation. A traditional approach to innovations - based on the results of own $\mathrm{R} \& \mathrm{D}$ centres, long lasting and expensive research protected against competition - is coming to an end. Other issues are important on the market: the time of reaction to consumer needs or the cooperation in an innovation chain, which enables companies to share costs and risks of innovation undertakings.

Innovation is becoming more and more global, hence the innovation model is more and more open ${ }^{8}$. In the table 2 there are different definitions of open innovation found in literature.

The open innovation model by Chesbrough is not the only one which adopts the open approach to innovation processes. There are other approaches employed in practice, based on similar rules and built on one foundation - openess, cooperation, using own and other's ideas, sharing knowledge. The critics of Chesbrough claim that the division into close and open models is artificial ${ }^{9}$. According to the authors, this debate has and will have rather a theoretical character and the idea of openess - old or new - is just a good solution for these enterprises, especially the Polish ones, where cooperation between science and industry is weak ${ }^{10}$.

\section{Open innovation - findings and Nokia case}

The empirical evidence on open innovation consists mainly of case studies, usually of large companies in technology-intensive industries. Open innovation, which is a very variable concept, and its importance for companies directly depends not only on their strategies but also on their structural characteristics (industry, size etc.) ${ }^{11}$.

Data on R\&D alliances between different companies and organisations are an important source of information, especially for the empirical measurement of open innovation. This is mainly because they reveal the number and types of companies' technology collaborations. Collaboration is described as the 'active participation in joint innovation projects with other organisations $^{\prime 2}$. It can involve the joint development of new products, processes or other 
innovations with customers and suppliers. What is more, horizontal work with other enterprises or public research bodies might be included.

The data from CIS-4 (the fourth Community Innovation Survey) show that collaboration is a crucial part of innovation activities in many firms, i.e. about one in ten of all companies (or one in four innovating companies) in Europe cooperated with a partner for their innovation activities between 2002 and 2004. Interestingly enough, large companies were four times more likely to collaborate than SMEs. As far as the latter are concerned, the rate of collaboration is fairly similar across countries (between 10 and $20 \%$ of all firms in more than half of the countries surveyed), but it varies widely for large companies. It should be remembered that the data reveal only the existence of some sort of collaboration, there is nothing said about its type or intensity.

Even though there are some differences, the industry distribution shows significant collaboration on innovation in both manufacturing and services. Not only do industries such as chemicals, pharmaceuticals and ICT (including software) typically having high levels of open innovation display a large number of technology collaborations, but it is true also in case of industries such as wholesale and retail, transport and communication ${ }^{13}$.

More specifically, companies collaborate on innovation most often with suppliers and customers. Co-operation with competitors and private R\&D labs and consultants is not of key importance. In most countries this general finding becomes obvious when partners break down the collaboration on innovation. It is the universities and government research institutes that are are generally considered a major source of knowledge transfer for the innovation activities of companies (especially in more upstream research and exploration activities). On the other hand, the CIS data show that collaboration with public research organisations, i.e. higher education or government research institutes, is less frequent. Moreover, large companies are much less passive in public research even though there is much more cross-country variation for large companies than for SMEs.

International technology collaboration, i.e. collaboration with foreign partners, plays an important role in the companies' innovation process. However, geographical proximity still seems to be valued. The share of European firms having partners in another European country ranges between 2\% (Italy, Romania, Spain, Bulgaria) and 12\% (Denmark, Luxembourg, Finland, Belgium). Collaboration with partners outside Europe is much less frequent, i.e. only between 2 and $6 \%$ of all companies in Europe are involved in it. As far as companies in other regions are concerned, collaboration on innovation with partners abroad varies a lot, ranging from less than $2 \%$ of all companies in Korea, Japan and Australia, to more than $8 \%$ in Canada and New 
Zealand. Similarly, larger companies tend to be more active in international collaboration on innovation than SMEs.

Data from the MERIT Co-operative Agreements and Technology Indicators (MERITCATI) database ${ }^{14}$ on R\&D partnerships and technology alliances indicate that these are becoming more international than before. From 1991 to 2001, new international technology alliances rose from 339 to 602 . Although the US-based firms' share in the overall total declined from $80 \%$ in 1991 to $73 \%$ in 2001 , they continued to take part in a large majority of strategic alliances. In the same period, the participation of non-Triad firms went up from $4 \%$ to $14 \%$. The industry composition of alliances shifted from information technology (which decreased from $54 \%$ to $28 \%$ ) to pharmaceuticals and biotechnology (which rose from $11 \%$ to $58 \%$ ) between 1991 and $2001^{15}$.

Finnish Nokia ${ }^{16}$ is an example of a company that has changed its innovation strategy, applying the open and networking model.

Between 1997 and 2002 the third generation of mobile telecmommunications appeared, i.e. the development of UMTS technologies began. In this period, Nokia had 48 strategic alliance agreements ( 25 were joint development agreements, 16 co-production contracts, 6 joint ventures and 1 standardization consortium).

When comparing 1997-1998 with the period 2001-2002, it is clear that both the number and character of the alliance networks has changed completely. In 2001-2002 Nokia engaged in almost twice as many alliances, i.e. 32 versus 60 alliance agreements. In this relatively short time span the partners and types of products developed in these alliances also changed, as will be explained below.

If we compare the capabilities that are searched for in innovation networks, it becomes obvious that especially software development has become more important for Nokia (see Table 3). In the period 1985-1996 more than half of all alliances were on telecommunications and almost one-sixth on both software and microelectronics. From 1997 to 2002, however, almost half of all alliance agreements were on software development and more than one-third - on telecommunications. In the period 2001-2002 even half of all alliance agreements were related to software development. Following $\mathrm{March}^{17}$ and Koza and Lewin ${ }^{18}$, this indicates that exploration of new capabilities (in this case software development) has become more important in the third trajectory of mobile telecommunications.

Nokia engaged in many strategic alliances in both the second and third trajectory of mobile telecommunication technology, though the nature of the innovation networks in the two consecutive trajectories is not the same. When comparing 1997-1998 with 2001-2002, 
the proportion of new partners in the third trajectory proves to be extremely high. More than $83 \%$ of the partners in 1997-1998 were completely new to Nokia (see Table 4) and also more than $88 \%$ of the partners in the period 2001-2002 were completely new to the company. This indicates that Nokia mainly searched for weak ties, rather than strengthened its relationships with strong ties. Although some of the partners are still in mobile telecommunications, like Ericsson, Matsushita, Motorola and Siemens, many new areas are being explored.

Table 3. Search for capabilities in innovation networks

\begin{tabular}{|c|c|c|c|c|}
\hline \multirow[b]{2}{*}{ Computers } & \multicolumn{2}{|c|}{ 1997-1998 } & \multicolumn{2}{|c|}{ 2001-2002 } \\
\hline & 12 & $(37.5 \%)$ & 8 & $(13.3 \%)$ \\
\hline Software & 13 & $(40.6 \%)$ & 30 & $(50.0 \%)$ \\
\hline Telecommunications & 4 & $(12.5 \%)$ & 17 & $(28.3 \%)$ \\
\hline Microelectronics & 0 & $(0 \%)$ & 1 & $(1.7 \%)$ \\
\hline Other & 3 & $(9.4 \%)$ & 4 & $(6.7 \%)$ \\
\hline Total & 32 & & 60 & \\
\hline
\end{tabular}

Source: CGCP (1997-2002). In: Dittrich (2008).

Table 4. New partners in Nokia's innovation network

\begin{tabular}{|l|c|c|}
\cline { 2 - 3 } \multicolumn{1}{c|}{} & $1997-1998$ & $2001-2002$ \\
\hline Number of partners & 12 & 43 \\
\hline New partners & 10 & 38 \\
\hline Proportion of new partners & $83.3 \%$ & $88.4 \%$ \\
\hline
\end{tabular}

Source: CGCP (1997-2002). In: Dittrich (2008).

Procter\&Gamble - a pioneer in open innovation - is another example ${ }^{19}$. The company made a decision to open their R\&D for the environment in 1999, after a long time of complete protection and confidentiality of its R\&D activities. Procter\&Gamble came up to a conclusion that since it had 8,600 scientists with the most modern and advanced knowledge making hundreds of new products, company should take advantage of over $1.5 \mathrm{mln}$ other scientists and their potential working somewhere else. They wanted their inventions to come also from outside the company. 


\section{Conclusions}

We are witnessing the emergence of a new paradigm in enterprises' activity - an open innovation model. The open innovation is a complete novelty in the concept of innovation and it stands for a cheaper and faster solution of problems in a global network compared with traditional methods. The $21^{\text {st }}$ century has stimulated visible market changes, which made enterprises modify their innovation models.

Global competition, a short product cycle, technological progress influence the fact that an innovation process is becoming more expensive and risky. Consequently, enterprises, while doing their research, start to share their risk with other companies and organizations. They apply the open innovation model and develop networks with other organizations.

\section{Notes}

1 Schumpeter (1960).

2 Janasz, Janasz, Świadek, Wiśniewska (2001), pp. 194-197.

3 Rothwell (1992).

4 Own study on the basis of: Nobelius (2004), pp. 369-375; Ahmed (2000), pp. 112-114; Baruk (2006), p. 122.

5 H. Chesbrough shows this approach giving examples of global concerns' innovation strategies (Xerox, IBM, Intel) in: Chesbrough (2003).

6 Chesbrough (2003).

7 Teece (1988).

8 See Zedtwitz, Gassmann (2002), pp. 1259-1285.

9 See Dahlander, Gann (2007). Chesbrough did research in huge American enterprises (eg. Lucent, Intel, IBM, 3Com, Millenium Pharmaceuticals), applying the openess model on a large scale. Authors doubt wheter it is possible to prore the phenomenon of openess in the economy.

${ }^{10}$ See Działalność innowacyjna przedsiębiorstw w Polsce (2009).

11 OECD (2008). Open Innovation...

12 OECD (2007).

${ }^{13}$ OECD (2008). Open Innovation...

${ }^{14}$ This database is a systematic collection of inter-firm partnerships which contains information on nearly 10,000 cooperative agreements, involving some 3,500 parent companies.

15 OECD (2008). The Internationalisation...

16 From: Dittrich (2008).

17 March (1991), pp. 71-87.

18 Koza. Lewin (1998), pp. 255-264.

19 Connect and Develop... (2006). 


\section{References}

Ahmed, P.K. (2000). Sixth generation innovation: innovation management systems into the future. European Journal of Innovation Management, No. 3.

Baruk, J. (2006). Zarządzanie wiedza i innowacjami. Toruń: Wydawnictwo Adam Marszałek.

Chesbrough, H. (2003). Open Innovation. The New Imperative for Creating and Profiting from Technology. Boston: Harvard Business School Press.

Chesbrough, H.W. (2002). Graceful exits and foregone opportunities: Xerox's management of its technology spin-off companies. Business History Review, No. 4.

Connect and Develop: Inside Procter \& Gamble's New Model for Innovation. (2006). Harvard Business Review, Vol. 84, No. 3.

Dahlander, L., Gann, D. (2007). How open is innovation? In: Appropriability, proximity, routines and innovation. Kopenhaga.

Dittrich, K. (2008). Nokia's strategic change by means of alliance networks. A case of adopting the open innovation paradigm? In: P. Sivarajadhanavel, D. Vellingiri (Eds.). Open Innovation: The Networked $R$ and D. Chennai, India: Icfai's Professional Reference Book Series, Icfai University Press.

Działalność innowacyjna przedsiębiorstw w Polsce. (2009). GUS, Warszawa.

Ernst, D. The New Geography of Innovation - Asia's role in global innovation networks. From http://www.apru.org/awi/workshops/economic_integration/slides/Nov\%209/5-4\%20 Dieter\%20Ernst.pdf.

Janasz, W., Janasz, K., Świadek, A., Wiśniewska, J. (2001). Strategie innowacyjne przedsiębiorstw. Szczecin: Wydawnictwo Naukowe Uniwersytetu Szczecińskiego.

Koza, M.P., Lewin, A.Y. (1998). The Co-evolution of Strategic Alliances. Organization Science, $9(3), 255-264$.

March, J.G. (1991). Exploration and Exploitation in Organizational Learning. Organization Science 2(1), 71-87.

Nobelius, D. (2004). Towards the sixth generation of R\&D management. International Journal of Project Management, Vol. 22, Issue 5.

OECD (2007). Science, Technology and Industry Scoreboard. Paris: OECD.

OECD (2008). Open Innovation in the Global Networks. Paris: OECD.

OECD (2008). The Internationalisation of Business R\&D. Evidence, Impacts and Implications. Paris: OECD.

Rothwell, R. (1992). Successful Industrial Innovation: Critical Factors for the 1990's. $R$ and $D$ Management, No. 22. 
Rothwell, R. (1994). Towards the fifth-generation innovation process. International Marketing Review, Vol. 11, No. 1, 7-31.

Schumpeter, J. (1960). Teoria rozwoju gospodarczego. Warszawa: PWN.

Teece, D. (1988). Technological change and the nature of the firm. In: Dosi et al. Technical change and aconomic theory. Pinter Publishers.

Zedtwitz, M., Gassmann, O. (2002). Market versus technology driven in R\&D internationalisation: Four different patterns of managing research and development. Research Policy, No. 32. 